\title{
Psychosurgery in the History of Stereotactic Functional Neurosurgery
}

\author{
Lara Rzesnitzek $^{a} \quad$ Marwan Hariz $^{\text {b, c }}$ Joachim K. Krauss ${ }^{d}$ \\ ${ }^{a}$ Charité Psychiatric University Hospital at St. Hedwigs Hospital, University Medicine Charité, Berlin, Germany; \\ ${ }^{b}$ UCL Institute of Neurology, Queen Square, London, UK; ' ${ }^{\mathrm{C}}$ Department of Clinical Neuroscience, Umeå University, \\ Umeå, Sweden; ${ }^{\mathrm{d}}$ Department of Neurosurgery, Medical School Hannover, MHH, Hannover, Germany
}

\section{Keywords}

Psychosurgery · Functional neurosurgery · Leucotomy · Thalamotomy · Anterior capsulotomy · Stereotaxy · History · Stereotactic surgery

\section{Abstract}

The paper invites to reappraise the role of psychosurgery for and within the development of functional stereotactic neurosurgery. It highlights the significant and long-lived role of stereotactic neurosurgery in the treatment of severe and chronic mental disorders. Stereotactic neurosurgery developed out of psychosurgery. It was leucotomy for psychiatric disorders and chronic pain that paved the way for stereotactic dorsomedial thalamotomy in these indications and subsequently for stereotactic surgery in epilepsy and movement disorders. Through the 1960s stereotactic psychosurgery continued to progress in silence. Due to the increased applications of stereotactic surgery in psychiatric indications, psychosurgery's renaissance was proclaimed in the early 1970s. At the same time, however, a public fearing mind control started to discredit all functional neurosurgery for mental disorders, including stereotactic procedures. In writing its own history, stereotactic neurosurgery's identity as a neuropsychiatric discipline became subsequently increasingly redefined as principally a sort of "surgical neurology," cut off from its psychiatric origin.

(c) 2020 The Author(s)

Published by S. Karger AG, Basel

\section{Introduction}

The history of "functional and stereotactic neurosurgery" is an intertwined process across the disciplines neurosurgery, neurophysiology, neuroradiology, neurology and psychiatry. As is always the case with history, the narrative may seem to change with the perspective taken. This is also the case with the history of what might be seen as two overlapping subtypes of functional neurosurgery: "stereotaxy" and "psychosurgery."

Some portions of this work were presented in a keynote lecture entitled "Psychosurgery in post-war Germany" at the 17th Quadrennial Meeting of the World Society for Stereotactic and Functional Neurosurgery, Berlin, Germany, June 27, 2017. karger@karger.com www.karger.com/sfn Karger $\stackrel{\text { ' }}{5}$
(C) 2020 The Author(s) Published by S. Karger AG, Basel

Karge Open access

This is an Open Access article licensed under the Creative Commons Attribution-NonCommercial-4.0 International License (CC BY-NC) (http://www.karger.com/Services/OpenAccessLicense), applicable to the online version of the article only. Usage and distribution for commercial purposes requires written permission.
Lara Rzesnitzek, MD

Charité Psychiatric University Hospital at St. Hedwigs Hospital University Medicine Charité

Große Hamburger 5-1, DE-110115 Berlin (Germany)

lara.rzesnitzek@charite.de 
In documenting the history of "functional neurosurgery," the chapter on functional neurosurgery for psychiatric diseases, "psychosurgery," is commonly formulated as a critique of leucotomy $[1,2]$. As a crude destructive procedure assumingly without justifiable theoretical neuropathological foundation, leucotomy is said to have been abandoned with the introduction of psychopharmacotherapy.

As for the history of "stereotactic neurosurgery," one gets the impression that it was a therapy developed for movement disorders and only later applied for psychiatric indications $[3,4]$. Especially deep brain stimulation (DBS) is presented as having been pioneered as an alternative to stereotactic ablation for the control of tremor in Parkinson's disease and to have only later found application in psychiatry $[5,6]$.

In fact, the usual narratives on the history of functional and stereotactic neurosurgery may not reflect the chronological historical facts, as has been shown in relation to the "untold" history of DBS [7]. Here we aim to recollect the role of psychosurgery in the history of lesional (non-DBS) stereotactic neurosurgery starting with stereotactic dorsomedial thalamotomy for psychiatric indication as the first stereotactic lesioning procedure performed in humans.

Methodologically, we provide a critical exegesis of the history as outlined in the major contemporaneous textbooks of the field in comparison with the original scholar sources and records. We review published lectures held at national and international conferences, articles in medical journals, material from hospital archives such as medical and surgical reports, books and proceedings of meetings, personal files, etc.

An attentive reading of the publications of Spiegel and Wycis' first lectures on the method they labelled "stereoencephalotomy" showed that the rationale to develop the procedure was to refine leucotomy and was also accordingly used by Spiegel and Wycis in the USA in cases of obsessions, depression, schizophrenia or child mental deficiency $[8,9]$.

In the present paper, we will demonstrate that also beyond the USA, stereotactic neurosurgery was primarily developed - and used - to replace leucotomy.

We delineate that functional stereotactic neurosurgery expanded into the treatment of pain, epilepsy and movement disorders (Huntington's and Parkinson's diseases, dystonia) only later. Furthermore, contrary to the common narrative of a disappearance of psychosurgery in the 1960s and its renaissance in the early1970s, we provide in a third step evidence that stereotactic psychiatric surgery had continued to live on and even advanced silently during the 1960s.

\section{From Leucotomy to Stereotaxis}

Spiegel's and Wycis' idea for thalamotomy as the first use of what they labelled "stereoencephalotomy" stemmed from their aversion against the devastating side effects of leucotomy [9-11].

Leucotomy had been introduced by the Portuguese neurologist António Egas Moniz (1874-1955), and was popularized by psychiatrist Walter Freeman (1895-1972) with neurosurgeon James Watts (1904-1994) under the label "frontal lobotomy" $[12,13]$. While the numbers of leucotomies or lobotomies increased considerably due to Freeman's promotion of "transorbital lobotomy" [14], the sometimes devastating side effects of lobotomy became increasingly evident $[15,16]$. New surgical non-stereotactic techniques were tried to minimize these, such as orbital undercutting, selective undercutting of Brodmann areas 9 and 10 (topectomy), open cingulotomy [17, 18].

Studies of autopsied lobotomized brains showed that the retrograde Wallerian degeneration affected mainly the thalamus, in particular the dorsomedial nucleus. This was shown already in 1947 by several workers including Freeman and Watts $[19,20]$. Thus, Spiegel and Wycis concluded that the beneficial effect of lobotomy in reducing emotional reactivity was by inducing a degeneration of the dorsomedial nucleus of the thalamus, which became the rationale to use that target for their first stereotactic procedure. They reasoned that lesioning directly at the thalamic level would allow creating the same effect as lobotomy but without the side effects provoked by the destruction of large areas of the frontal lobes [10].

\section{A Therapy for Psychosis and Intractable Pain}

Asides from psychosis, leucotomies were soon used in the therapy of chronic pain; Walter Freeman and James Watts even changed the title of the 1942 Psychosurgery monograph for its second edition in 1950 to include pain as indication: Psychosurgery - In the Treatment of Mental Disorders and Intractable Pain [13, 21].

A specific focus on the therapy of pain was also given at the 4th International Congress of Neurology held in Paris in September 1949. Unsurprisingly, Spiegel and Wycis also presented their results here under the heading "Mesencephalotomy and mesencephalothalamotomy for the treatment of unbearable pain" [22].

At that Congress, the French psychiatrist Jean Talairach (1911-2007) presented his own stereotactic system for the electrocoagulation of the posterior ventral thalamic region for the treatment of therapy-resistant pain [23]. Moreover, at that same meeting, Talairach presented the anterior limb 


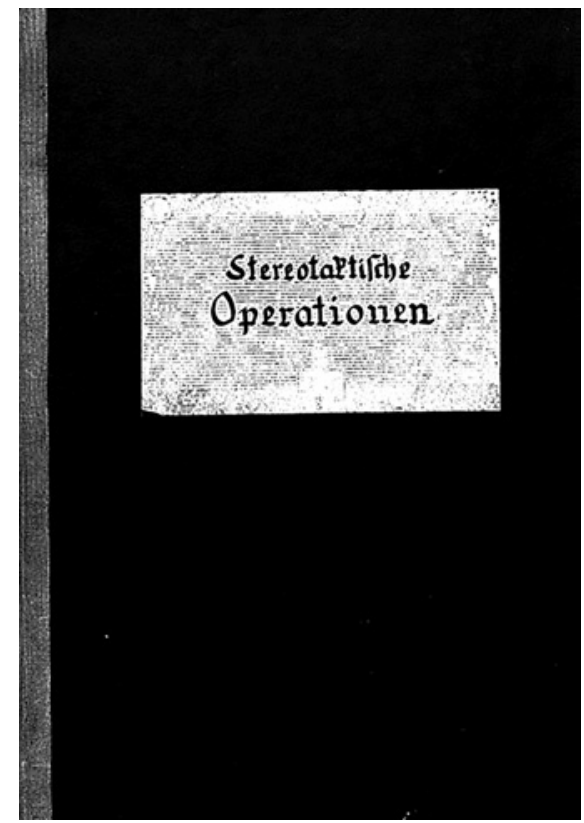

Fig. 1. Freiburg stereotactic surgical record book. Source: private archive of Prof. Joachim Krauss.

of the internal capsule as a target to treat mental disorders under the title "Lobotomie préfrontale limitée par électrocoagulation des fibres thalamo-frontales à leur émergence du bras antérieur de la capsule interne" [24, 25].

Also at the Paris Congress in 1949, the renowned neurologist Alphonse Baudouin (1876-1956) and the neurosurgeon Pierre Puech (1897-1950) presented cases of thalamotomy both for pain and schizophrenia [26]. These interventions had been performed with yet another stereotactic device constructed according to Baudouin's advice [27]. In 1950, Puech published a textbook solely devoted to psychosurgery: thalamotomy was used as a treatment for pain or for schizophrenia [28].

By the end of the 1940s, two other types of stereotactic systems were introduced: one by Lars Leksell (19071986) in Sweden and the other by Traugott Riechert (1905-1983) in West Germany.

While the thesis of psychiatrist Torsten Herner, who worked with Leksell, hinted that also in Sweden the primary application of the stereotactic device was for the treatment of pain, schizophrenia, depression, obsession and compulsions and neurotic fear [29,30], in Germany the evidence that stereotactic neurosurgery for pain and psychiatric disorders evolved from leucotomy was more explicit [31,32].

A look inside the Freiburg chronological stereotactic surgical record book shows that "stereotaxy" there was

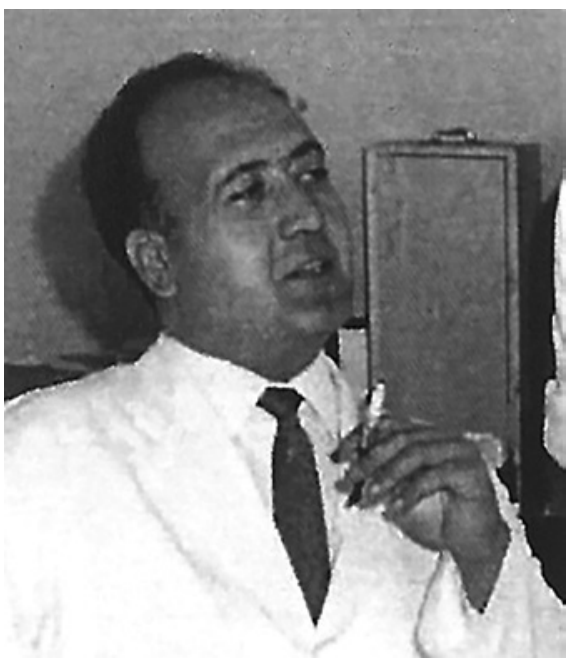

Fig. 2. Photo of Prof. Fritz Mundinger (1924-2012), leading stereotactic neurosurgeon in Germany who cooperated with Traugott Riechert, Freiburg, in the early 1960s. Source: private archive of Prof. Joachim Krauss.

first used for pain and psychiatric disorders, then introduced for epilepsy, then torsion dystonia and last for Parkinson's disease (Fig. 1).

\section{Stereotaxy as "Layered Leucotomy"}

These early Freiburg stereotactic interventions were performed by Traugott Riechert, neurosurgeon from Frankfurt am Main, who had been recruited to Freiburg by the psychiatrist Kurt Beringer (1893-1949) to lead the newly established neurosurgery unit of the Psychiatric Neurological Clinic in 1946. Riechert had initially performed leucotomies to treat pain, chronic schizophrenia and sometimes severe behavioural disorders in children $[33,34]$.

As was the case for Spiegel and Wycis, the rationale for Riechert for introducing stereotaxy was to avoid the severe complications and side effects of standard leucotomy. Riechert aimed to improve psychosurgery by performing leucotomy in a more precise step-by-step way with his stereotactic system, a method that Riechert called "layered," "graduated" or "stepped" leucotomy [31, 35]. Riechert was assisted by Max Wolff (1908-?), doctor in physics and medicine, who had initially enabled the construction of the Freiburg stereotactic apparatus, and later by neurosurgeon Fritz Mundinger (1924-2012) (Fig. 2).

The idea of performing "stepped" leucotomy originated particularly from the work of the neuropathologist Rolf Hassler (1914-1984) (Fig. 3). By 1948, Hassler's neuroanatomical studies on leucotomy had already indicated that the 


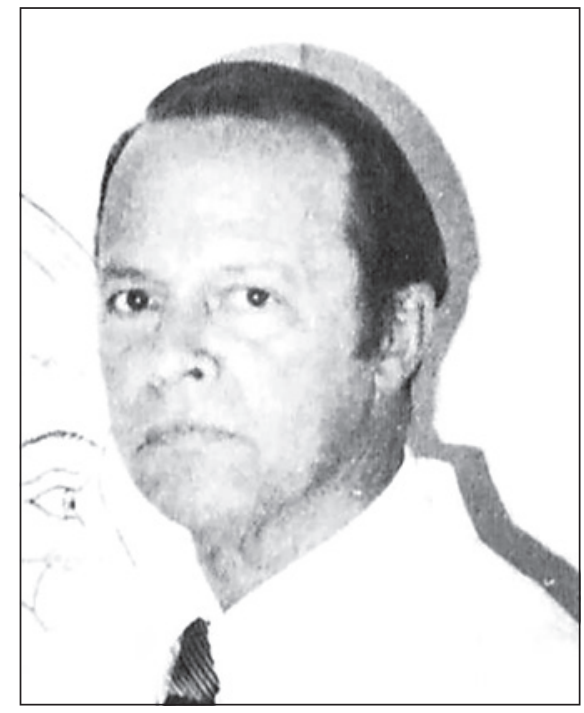

Fig. 3. Photo of Prof. Rolf Hassler (1914-1984). Source: Hessisches Ärzteblatt, Heft 9, 1983:739.

therapeutic effects of leucotomy were associated with retrograde degeneration of certain thalamic nuclei and should therefore also be achieved by targeted intervention directly at the thalamic level, while preserving frontal brain tissue and causing thus less side effects $[36,37]$. Of course, this was similar to Spiegel and Wycis' reasoning at the very same time and Freeman and Watts' theory on the effectiveness of leucotomy published later in $1950[8,21]$.

Since the neurosurgical unit in Freiburg was situated until 1955 within the psychiatric-neurological clinic, patients were continuously psychiatrically evaluated. In Riechert's experience, it proved "especially impressive," that

even after several surgeries, the severe cerebral organic state lasting typically for days or weeks after a standard leucotomy did not appear at all. The drastic psychomotor slowing, often accompanied by a peculiar somnolence, disorientation, amnestic disorders, faecal and urinary incontinence were not present with this method of stepped coagulations or only to a minor degree after a series of surgeries [38].

It might be noteworthy that also in the German Democratic Republic (East Germany) the first stereotactic operation, performed in 1957, was a "stepped leucotomy" [39].

Stereotaxy, the Tale of the "Renaissance" of Psychosurgery in the 1970s and the Persistence of Leucotomy

After the 1st International Congress for Psychosurgery held in Lisbon in 1948 where Spiegel and Wycis had de- livered their lecture "Thalamotomy for Mental Disorders," 22 years passed until the 2nd International Congress for Psychosurgery was convened in Copenhagen in 1970.

Although in 1950, at the 1st International Congress for Psychiatry in Paris, standard leucotomy, transorbital leucotomy, topectomy and orbitofrontomedial undercutting were discussed, stereotactic thalamotomy had been missing. In 1957, the 2nd International Congress for Psychiatry in Zürich had schizophrenia as a main topic; however, neither standard leucotomy nor stepped leucotomy or thalamotomy were addressed: psychosurgery seemed to have disappeared.

Yet, at the 3rd International Congress for Psychosurgery in Cambridge in 1972 there was an introductory lecture delivered by Swedish psychiatrist Gösta Rylander (1903-1979) with the title "Renaissance of psychosurgery" [40], where he stated that psychosurgery owed its renaissance to stereotactic surgery.

Leucotomy was said to have vanished due to the growing public critique, especially its indiscriminate use and its severe side effects against the backdrop of the introduction of chlorpromazine in 1952 and haloperidol in 1958. At the end of the 1960s however, recognizing the chagrin about the finally not almighty neuroleptics, "stereotaxy" again promised to be the technique to place smaller, more accurate targeted lesions with less side effects and even more therapeutic effect. Put bluntly, it seemed that after leucotomy had disappeared, psychosurgery celebrated its revival by the end of the 1960s thanks to the stereotactic method.

This point of view on history is seemingly supported by a somehow similar yet time-lagged development in stereotactic neurosurgery for movement disorders: with the introduction of L-dopa in 1968, stereotactic surgery declined, and because of the beneficial effects of drug therapy, patients with Parkinson's disease no longer needed surgery [41]. The rationalizing continues that because of this situation, stereotactic centres started to look for - or revive - "new" indications. Ironically one can posit that it was psychosurgery that contributed to the rescue of stereotaxis as a surgical technique after it had been used for treating Parkinson's disease and movement disorders.

Against this exegesis of the historical development speaks that the lectures held at the 2nd and the 3rd International Congresses for Psychosurgery in Copenhagen in 1970 and in Cambridge in 1972 presented cases of stereotactic psychosurgery that had been performed continuously since the early 1950s. At the 2 nd International Con- 
gress for Psychosurgery in 1970, for example, the psychiatrist and neurologist Fritz Roeder (1906-1988) and the neuropathologist Hans Orthner (1914-2000) from Göttingen presented stereotactic interventions for "obsessions and compulsions, schizophrenia, erethic oligophrenia, severe autoaggressions in idiotic children and hypochondriac depression" that they had performed between 1955 and 1970 [42]. Moreover, they presented results of hypothalamotomies for paedophilia, a project which they had started in 1962 [43].

Remarkably, stereotactic psychosurgery had not only survived in some Western European countries, but also in other sites:

At the 1970 Psychosurgery congress, Keiji Sano (19202011) from Tokyo presented his experience with stereotactic psychosurgery that had been performed since the early 1960s; lesions had been placed in the posterior hypothalamus for calming aggressive and restless behaviour [44].

Also in Tokyo, the psychiatrist Hirotaro Narabayashi (1922-2001), turned stereotactician, who had introduced stereotactic neurosurgery by 1949 , started with stereotactic amygdalotomies for psychomotor epilepsy and then for aggressive behavioural disorders in oligophrenic children in 1951 [45-47].

Such interventions in patients with erethic aggressive imbecility and oligophrenia were used in several countries during the 1960s, even if they were not always published and seldom presented at congresses. One exception is Hassler's and the neurosurgeon Gert Dieckmann's (1925-2007) lecture at the 4th European Congress of Neurosurgery in Prague, in the summer of 1971 [48]. The subject might have come up there because in former Czechoslovakia Pavel Nádvorník (*1923) also performed stereotactic surgery for these indications [49].

Hence, psychiatric surgery was not dead during the 1960s: one just did not advertise it much. As Fritz Mundinger put it in his review on psychiatric surgery in 1974: it had advanced silently ("in der Stille weiterentwickelt" [50]):

Since the 1950s, a variety of new targets and techniques had been developed such as anterior capsulotomy, cingulotomy, amygdalotomy or hypothalamotomy. Stereotactic lesions were done mechanically by leucotome, by radiofrequency coagulation, by delivering interstitial irradiation or by gamma knife radiosurgery, and by several other means [51]. Although by the end of the 1950s, tremor, Parkinson's disease, dystonia and epilepsy had become the main indications, stereotactic interventions for psychiatric disorders were still performed, but only mentioned "en passant," as for example at the 1st Internation-

Psychosurgery in the History of

Stereotactic Functional Neurosurgery

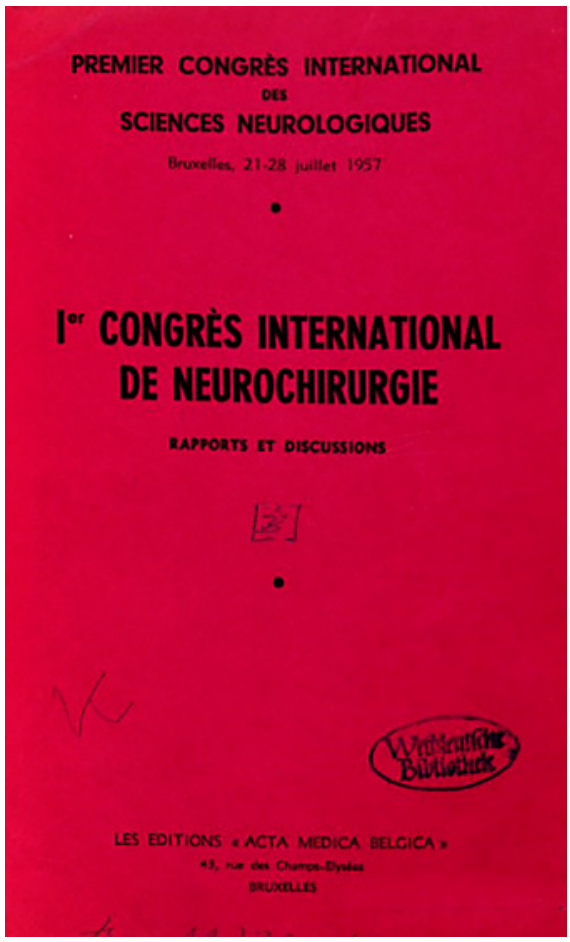

Fig. 4. Cover of Premier Congrès International de Neurochirurgie, Bruxelles 1957, rapports et discussions [52].

al Congress of Neurosurgery in Brussels in 1957 (Fig. 4) [52].

Moreover, stereotactic psychosurgery did not supersede leucotomy. At the 4th International Congress for Psychiatry in 1966 for example, Japan neurosurgeon Sadao Hirose (1918-2007) presented a continued use of prefrontal leucotomy [53]. Perhaps this was one reason why Japan was among the countries that banished psychosurgery the most harshly in the mid-1970s [54]. However, the worldwide "antipsychosurgery campaign" was "merely a part of a general attack against most forms of psychiatric treatment" as American neurosurgeon Vernon Mark (1925-2014) rightly complained in 1974 [55]. Within the antipsychiatry movement, a series of monographs and papers all published in the 1960s until early 1970s [56-58], had questioned the theoretical underpinnings of psychiatry as a medical discipline. Any form of somatic psychiatric therapy was estimated "modern therapeutic totalitarianism," e.g. a mean to enforce discipline inside the assumingly repressive regime of a psychiatric hospital [59]. While initially electroconvulsive therapy, formerly called "electroshock therapy" was the focus of defamation [59], the public attention shifted to psychosurgery with the 1970 published book Violence and the 
Brain [60]. Herein, American neurosurgeon Vernon Mark together with psychiatrist Frank R. Ervin (19262015) made the suggestion to use psychosurgery for severe aggression in criminal offenders. Fired finally by the 1975 American movie of Ken Kesey's 1962 book One Flew over the Cuckoo's Nest, the antipsychiatric sociopolitical debate brought electroconvulsive therapy and psychiatric surgery to a temporary halt in many countries. The first "shocked" and then leucotomized McMurphy played by Jack Nicholson incorporated the misuse of psychiatry in general and of psychosurgery in particular. The proclaimed renaissance of psychosurgery in 1972 was shortlived. Psychosurgery became legally forbidden in several places $[40,61]$.

\section{Conclusions}

Our reappraisal of the history of functional stereotactic neurosurgery highlights the central, albeit discrete, role of psychosurgery.
Against the widely published stereotactic psychosurgical experience of Talairach, Puech, Riechert, Laitinen, Leksell and many others, the contemporary history of the stereotaxis tends to minimize the place of psychosurgery $[3,41,62-66]$. Evidently, due to the antipsychiatry movement, psychosurgery had become a symbol for political despotism with societies in fear of mind control almost all over the world since the 1970s. Stereotactic functional neurosurgery had to redefine itself as solely neurological surgery, for movement disorders, pain and epilepsy. As a consequence, stereotactic surgery remains very rarely offered today for treatment of refractory severe psychiatric illness. Therefore, its past experiences may well deserve a careful reconsideration.

\section{Disclosure Statement}

L.R.: no conflict of interest. J.K.K.: is a consultant to Medtronic and Boston Scientific, and received honoraria from St. Jude/Abbott. M.H.: received honoraria and travel expenses from Medtronic and Boston Scientific for speaking at meetings.

\section{References}

1 Iskandar BJ, Nashold BS Jr. History of functional neurosurgery. Neurosurg Clin N Am. 1995 Jan; 6(1):1-25.

2 Boulis NM. Revenge of the nerds: functional neurosurgery, past and future. Congress of Neurological Surgeons - Congress Quarterly Spring 2017. Available from: https://www. cns.org/publications/congress-quarterly/ congress-quarterly-spring-2017/revenge_of_ the nerds

3 Nashold BS. The history of stereotactic neurosurgery. Stereotact Funct Neurosurg. 1994; 62(1-4):29-40.

4 Gildenberg PL. General Concepts of Stereotactic Surgery. In: Lunsford LD, editor. Modern Stereotactic Neurosurgery. Topics in neurological surgery. Volume 1. Boston (MA): Springer; 1988. pp. 3-11.

5 Kopell BH, Greenberg B, Rezai AR. Deep brain stimulation for psychiatric disorders. J Clin Neurophysiol. 2004 Jan-Feb;21(1):5167.

6 Jackim LW. Revolution in neurosurgery marches into refractory psychiatric illness. Behav Healthc Tomorrow. 2005 Feb;14(1): 23-5.

7 Hariz MI, Blomstedt P, Zrinzo L. Deep brain stimulation between 1947 and 1987: the untold story. Neurosurg Focus. 2010 Aug;29(2 E1):E1.

8 Rzesnitzek L, Hariz M, Krauss JK. The origins of human functional stereotaxis: a reappraisal. Stereotact Funct Neurosurg. 2019;97(1): $49-54$.
9 Spiegel EA, Wycis HT, Freed H, Lee AJ. Stereoencephalotomy. Trans Am Neurol Assoc. 1948;73(73 Annual Meet):160-3.

10 Spiegel EA, Wycis HT, Marks M, Lee AJ. Stereotaxic Apparatus for Operations on the $\mathrm{Hu}$ man Brain. Science. 1947 Oct;106(2754):34950.

11 Spiegel EA. This week's citation classic. 1983 Aug;33:325. Available from: http:// garfield.library.upenn.edu/classics1983/ A1983RB10700001.pdf

12 Egas Moniz A. Tentatives opératoires dans le traitement de certaines psychoses. Paris: Masson; 1936

13 Freeman W, Watts J. Psychosurgery: Intelligence, Emotion and Social Behavior Following Prefrontal Lobotomy for Mental Disorders. Springfield (IL): Charles C Thomas; 1942. https://doi.org/10.1037/11151-000.

14 Freeman W. Transorbital lobotomy. Am J Psychiatry. 1949 Apr;105(10):734-40.

15 Hutton EL. Personality changes after leucotomy. J Ment Sci. 1947 Jan;93(390):31-42.

16 Hoffman JL. Clinical observations concerning schizophrenic patients treated by prefrontal leukotomy. N Engl J Med. 1949 Aug; 241(6):233-6.

17 The Royal Society of Medicine, editor. Proceedings of the Royal Society of Medicine, Supplement of Volume 42. Section of Psychiatry. Anglo-American symposium on psychosurgery, neurophysiology and physical treatments in psychiatry. London: Longmans, Green \& Co; 1949.
18 Swayze VW 2nd. Frontal leukotomy and related psychosurgical procedures in the era before antipsychotics (1935-1954): a historical overview. Am J Psychiatry. 1995 Apr;152(4): 505-15.

19 Freeman W, Watts JW. Retrograde degeneration of the thalamus following prefrontal lobotomy. J Comp Neurol. 1947 Feb;86(1):6593.

20 Meyer A, Beck E, McLARDY T. Prefrontal leucotomy; a neuro-anatomical report. Brain. 1947 Mar;70(1):18-49.

21 Freeman W, Watts J. Psychosurgery. In the Treatment of Mental Disorders and Intractable Pain. 2nd ed. Springfield (Illinois): Charles C Thomas; 1950.

22 Wycis HT, Spiegel EA. Mesencephalotomy and mesencephalothalamotomy for the treatment of unbearable pain. IV Congres Neurologique International Paris 5-10 septembre 1949. Volume III. Paris: Masson; 1949. pp. 310-3.

23 Talairach J, Hecaen H, David M, Monnier M. Traitement de certaines algies rebelles par electrocoagulation de la région postéro-ventrale du thalamus [Treatment of some forms of chronic pain with electrocoagulation of the posterior-ventral thalamic region]. IVe Congrès Neurologique International, Paris 5-10 septembre 1949. Rev Neurol. 1950;83(II):45.

24 Talairach J, Hecaen H, David M. Lobotomie préfrontale limitée par électrocoagulation des fibres thalamo-frontales à leur émergence du bras antérieur de la capsule interne. Rev Neurol. 1949;83(I):59. 
25 Zanello M, Pallud J, Baup N, Peeters S, Turak B, Krebs MO, et al. History of psychosurgery at Sainte-Anne Hospital, Paris, France, through translational interactions between psychiatrists and neurosurgeons. Neurosurg Focus. 2017 Sep;43(3):E9.

26 Baudouin A, Puech P. Sur quelques essais de thalamotomie [Some trials of thalamotomy]. In: IVe Congrès Neurologique International, Paris 5-10 septembre 1949. Paris: Masson; 1949. Vol II, p. 44-5.

27 Baudouin A, Rémond A. Sur un appareil stéréotactique applicable à l'homme [About a stereotactic apparatus to be applied to man]. In: IVe Congrès Neurologique International, Paris 5-10 septembre 1949. Paris: Masson; 1949. Vol II, p. 132.

28 Puech P, Guilly P. Lairy-Bounes GC- Introduction à la psychochirurgie [Introduction to Psychosurgery]Paris: Masson; 1950.

29 Leksell L. A stereotactic apparatus for intracerebral surgery. Acta Chir Scand. 1949;99:22933.

30 Herner T. Treatment of Mental Disorders with Frontal Stereotaxic Thermo-Lesions - A Follow up Study of 116 Cases. Copenhagen: Ejnar Munksgaard; 1961.

31 Riechert $\mathrm{T}$, Wolff M. Über ein neues Zielgerät zur intrakraniellen elektrischen Ableitung und Ausschaltung [About a new device for guiding intracranial electrical mesurement and lesioning]. Arch Psychiatrie Z Neurol. 1951;186(2):225-30.

32 Riechert T. Die psychochirurgischen Eingriffe mit besonderer Berücksichtigung der gezielten Hirnoperationen [Psychosurgical interventions with special mention of guided brain operations]. Langenbecks Arch. 1953; 276(1):101-9.

33 Riechert T. Die Durchschneidung thalamofrontaler Bahnen bei unbeeinflussbaren chronischen Schmerzen [The transection of thalamo-frontal circuits in treatment refractory chronic pain]. Med Klin. 1949;44(22):689-92.

34 Rzesnitzek L. The introduction of leucotomy in Germany: national Socialism, émigrés, a divided Germany and the development of neurosurgery. Hist Psychiatry. 2019 Sep;30(3): 325-35.

35 Riechert T, Wolff M. Die technische Durchführung von gezielten Hirnoperationen [The technical procedure of guided brain operations]. Arch Psychiatrie Z Neurol. 1953;190: 297-316.

36 Hassler R. Über die anatomischen Grundlagen der Leukotomie [About the anatomical foundations of leucotomy]. Fortschr Neurol Psychiatr. 1950;18:351-67.

37 Hassler R, Riechert T. Indikationen und Lokalisationsmethode der gezielten Hirnoperationen [Indications and localisation method for guided brain operations]. Nervenarzt. 1954 Nov;25(11):441-7.

38 Riechert T. Die Ausschaltung thalamo-corticaler Bahnen und anderer Hirnstrukturen mit Hilfe eines Zielapparates [The disconnection of thalamo-cortical circuits and other brain structures using a guiding apparatus]. Vortrag auf der 69. Tagung der Deutschen Gesellschaft für Chirurgie 16.-19. April 1952 in München. Langenbecks Arch. 1953;273:560-5.

39 Neubauer C. Zur Geschichte der stereotaktischen Neurochirurgie. Dissertation Universität Leipzig 1988.

40 Rylander G. The renaissance of psychosurgery. In: Laitinen LV, Livingston KE, editors. Surgical approaches in psychiatry. Proceedings of the Third International Congress of Psychosurgery, August 14th-18th 1972, Cambridge. Lancaster: MTP; 1973. p. 3-12.

41 Gildenberg PL. The history of surgery for movement disorders. Neurosurg Clin N Am. 1998 Apr;9(2):283-94.

42 Orthner H, Müller D, Roeder F. Stereotaxic psychosurgery - techniques and results since 1955. In: Hitchcock E, Laitinen L, Vaernet K, editors. Psychosurgery: proceedings of the Second International Conference on Psychosurgery 1970, Copenhagen. Springfield: Thomas Publisher; 1972. p. 377-90.

43 Roeder F, Orthner H, Müller D. The stereotaxic treatment of pedophilic homosexuality and other sexual deviations. In: Hitchcock E, Laitinen L, Vaernet K, editors. Psychosurgery: proceedings of the Second International Conference on Psychosurgery 1970, Copenhagen. Springfield: Thomas Publisher; 1972. p. 87-111.

44 Sano K. Results of stimulation and destruction of the posterior hypothalamus in cases with violent, aggressive or restless behaviour. In: Hitchcock E, Laitinen L, Vaernet K, editors. Psychosurgery: proceedings of the Second International Conference on Psychosurgery 1970, Copenhagen. Springfield: Thomas Publisher; 1972. p. 57-75.

45 Ohye C. History of stereotactic surgery in Japan. In: Lozano AM, Gildenberg PL, Tasker RR, editors. Textbook of stereotactic and functional surgery. Berlin/Heidelberg: Springer; 2009. p. 58-63.

46 Narabayashi H. Stereotaktische Amygdalektomie zur Behandlung von abartigem Verhalten mit oder ohne Anomalien des EEG. In: World Federation of Neurosurgical Societies, editor. Second International Congress of Neurological Surgery, Washington DC, October 14-20, 1961. Amsterdam: Exerpta Medica; 1961. p. D140-D141.

47 Narabayashi H, Uno M, Saito Y, Yoshida M, Nagahata M. Long range results of stereotaxic amygdalotomy for behavior disorders. Confin Neurol. 1966;27(1):168-71.

48 Hassler R, Dieckmann G. Violence against oneself and against others as a target for stereotaxic psychosurgery (Erethismic imbecility and temporal lobe epilepsy). In: Fusek I, Kunc Z, editors. Present limits of neurosurgery - proceedings of the Fourth European Congress of Neurosurgery, June 28 - July 2 , 1971, in Prague. Prague: Czechoslovak Medical Press; 1972. p. 477-82.

49 Nadvornik P, Pogady J, Sramka M. The results of stereotactic treatment of the aggressive syndrome. In: Laitinen LV, Livingston KE, edi- tors. Surgical approaches in psychiatry. Proceedings of the Third International Congress of Psychosurgery, August 14th-18th, 1973, Cambridge. Lancaster: MTP; 1973. p. 125-8.

50 Mundinger F. Psychiatrische Chirurgie [Psychiatric surgery]. Z Allgemeinmed. 1974 Jul; 50(19):856-9.

51 Binder DK, Iskandar BJ. Modern neurosurgery for psychiatric disorders. Neurosurgery. 2000 Jul;47(1):9-21.

52 Riechert T. Die stereotaktischen Hirnoperationen in ihrer Anwendung bei den Hyperkinesien (mit Ausnahme des Parkinsonismus), bei Schmerzzuständen und einigen weiteren Indikationen (Einführen von radioaktiven Isotopen usw.) [The stereotactic brain operations and their application in hyperkinesias (with the exeption of parkinsonism), in pain and in some other indications (introduction of radiating isotopes etc.)]. In: Premier Congrès International de Neurochirurgie, Bruxelles 1957, rapports et discussions. Brussels: Les Editions Acta Medica Belgica; 1957.p. 121-59.

53 Hirose S. Present trends in psychosurgery. In: Lopez Ibor JJ, editor. Proceedings of the Fourth World Congress of Psychiatry - Madrid, 5-11 September 1966, Part 2 - Symposia. Amsterdam: Excerpta Medica Foundation; 1968. p. 1156-66.

54 Nudeshima J, Taira T. A brief note on the history of psychosurgery in Japan. Neurosurg Focus. 2017 Sep;43(3):E13.

55 Mark VH. Psychosurgery versus anti-psychiatry. Boston Univ Law Rev. 1974 Mar;54(2): 217-30.

56 Szasz TS. The myth of mental illness. London: Paladin; 1961.

57 Goffman E. Asylums. Essays on the Social Situation of Mental Patients and Other Inmates. Garden City (NY): Doubleday; 1961.

58 Rosenhan DL. On being sane in insane places. Science. 1973 Jan;179(4070):250-8.

59 Szasz TS. From the slaughterhouse to the madhouse. Psychotherapy (Chic). 1971;8(1):64-7.

60 Mark VH, Ervin FR. Violence and the Brain. New York: Harper and Row; 1970.

61 Valenstein E. Great and Desperate Cures: The Rise and Decline of Psychosurgery and other Radical Treatments for Mental Illness. New York: Basic Books; 1986.

62 Gildenberg PL. The history of stereotactic neurosurgery. Neurosurg Clin N Am. 1990 Oct; $1(4): 765-80$.

63 Gildenberg PL, Krauss JK. History of Stereotactic Surgery. In: Lozano AM, Gildenberg PL, Tasker RR, editors. Textbook of stereotactic and functional surgery. Berlin, Heidelberg: Springer; 2009. pp. 3-33.

64 Gildenberg PL. History repeats itself. Stereotact Funct Neurosurg. 2003;80(1-4):61-75.

65 Cif L, Hariz M. Seventy years of pallidotomy for movement disorders. Mov Disord. 2017; 32(7):972-82.

66 Hariz M, Tabrizi S. Patients with Huntington's disease pioneered human stereotactic neurosurgery 70 years ago. Brain. 2017 Sep; 140(9):2516-9.
Psychosurgery in the History of

Stereotactic Functional Neurosurgery
Stereotact Funct Neurosurg 2020;98:241-247 DOI: $10.1159 / 000508167$ 